\title{
Seroprevalence of Bovine Adenovirus and Enterovirus Antibodies Reveals Different Infection Dynamics in Cattle Herds
}

\author{
Chris Kelli Gras, Meriane Demoliner, Ana Karolina Antunes Eisen, Fernando Rosado Spilki \& Andréia Henzel
}

\begin{abstract}
Background: Bovine enterovirus (BEV) and bovine adenovirus (BAV) are widely distributed in cattle population, and are among possible causes of gastroenteritis and respiratory disease, respectively, although the infection is more often subclinical. BAV infection may be also related to conjunctivitis, and may lead to severe infections and death in immunosuppressive calves. BEV infections have been associated with disorders of respiratory and reproductive tracts, and diarrhea. There is little available information about BAV and BEV in Brazil; however the main of the present study was to investigate the presence of antibodies against these viruses in cattle from some counties of the Rio Grande do Sul (RS), Brazil.

Material, Methods \& Results: A total of 415 bovine serum samples collected in 2015 year to detect neutralizing antibodies against BEV and BAV by Virus neutralization (VN) assay were performed. The serum samples were gently provided from Setor de Virologia da Universidade Federal de Santa Maria (SV-UFSM). The samples came from bovine with a history or report of clinical cases of diarrhea, respiratory and reproducible disorders and/or abortion suggestive of Leucosis, Bovine Viral Diarrhea Virus (BVDV) and/or Bovine herpesvirus type 1 and 5 (BoHV-1 and 5) infections. The samples are originated as from dairy and beef herd cattle in the following regions from RS State: Southwest, Northeast, Northwest, West, Southeast, Midwest and Metropolitan regions; and were classified according to the origin, gender and age. The serum samples were tested against $100 \mathrm{TCID} 50 / \mathrm{mL}$ of (tissue cellular infection dose $50 / \mathrm{mL}$ ) of previously characterized $\mathrm{BEV}$ and BAV-3 isolates. Serial dilution of the serum was performed in duplicate, starting at 1:5 up to $>1: 640$ for BEV and at $1: 2$ to $>1: 256$ for BAV in 96 wells plates. The serum and virus mixture was incubated in $37^{\circ} \mathrm{C}$ for $4-6 \mathrm{~h}$ and then a suspension of CRIB cells was added to each well. The plates were incubated in $37^{\circ} \mathrm{C}$ and $5 \% \mathrm{CO}_{2}$ for three days for $\mathrm{BEV}$ and five days for BAV assay. Neutralization titers were calculated as the reciprocal of the highest serum dilution able to avoid the cytopathic effect. A total of $99.7 \%$ (414/415) serum samples showed neutralizing antibodies to BAV and/or BEV. 99.2\% (411/414) showed neutralizing antibodies against only BEV and $97.3 \%$ (403/414) were seropositive only to BAV3. Regarding the sex of the analyzed population, males corresponded to $41.6 \%(173 / 415)$ and female $30.3 \%$ (126/415) of the total. From BEV seropositive samples, a higher frequency of neutralizing antibodies titers of 1:320, regarding $22.1 \%$ (91/411) of samples and for BAV-3 the titers > 1:256 were more prevalent, 72.2\% (291/403) of seropositive.

Discussion: The data in the present study showed that the frequency of neutralizing antibodies was high for both viruses as well as co-infection was prevalent; demonstrated that both viruses are actively circulating in the bovine population. However reinfections with BEV may be related to a higher proportion of animals presenting strong humoral immunity. Since BAV and BEV are normally related to subclinical infections, in the absence of clinical cases and high levels of herd immunity, it could be inferred that no other preventive measures need to be taken in these herds until no clear overt of clinical signs is noticed. In another hand, is important research these viruses in animals with signs historic of respiratory tract disease, reproductive disorders and diarrhea.
\end{abstract}

Keywords: BAV-3, BEV, neutralizing antibodies, VN. 


\section{INTRODUCTION}

Rio Grande do Sul (RS) State, is the sixth largest producer of herd cattle in Brazil, representing $15 \%$ of gross domestic product of the State. Nevertheless, gastroenteric and respiratory disorders are a main cause of losses that compromise the beef and dairy livestock development [13,18]. Different pathogens are associated to these disorders, which viruses are considered the mainly agent enrolled. Among the many viruses responsible for enteric diseases are BEV and at respiratory disease is associated BAV [19,20,25].

$\mathrm{BEV}$ is a RNA virus, non enveloped belonging to Picornaviridae family and have been classified into two genetic groups, BEV-1 and 2, more recently reclassified as EV-E and F $[9,26]$. BEV may cause asymptomatic or mild infectious in cattle, besides abortion and diarrhea $[3,4,9,14]$. BAV is a DNA non-enveloped virus, member of Adenoviridae family. The infection in adults is usually asymptomatic and recurrent, and when sings are present, respiratory distress, nasal and ocular discharges and hyperthermia may be observed, often complicated by secondary bacterial infections $[1,17,20,23,25]$. BAV may also be associated with calf weakness syndrome, characterized by newborn weakness, suckling reluctance, gait difficult, and progress to caquexia [4].

Infected cattle may spread BEV and BAV by feces and easily spreading in the environment $[15,22]$. Wild ruminants may also play a role in BEV and BAV transmission to domestic cattle $[5,10,15,22]$.

Studies about distribution and/or isolation for BEV and BAV are yet rare in Brazil. The main of present study was to verify the frequency of neutralizing antibodies against both viruses in bovine population raised some regions of RS, Brazil.

\section{MATERIALS AND METHODS}

Samples

A total of 415 bovine serum samples were gently donated from Setor de Virologia, Universidade Federal de Santa Maria (SV-UFSM). These samples were submitted to SV-UFSM for routine serodiagnosis and clinical history suggestive of Leucosis, Bovine Viral Diarrhea Virus (BVDV) and/or Bovine herpesvirus type 1 and 5 (BoHV-1 and 5) infections. The serum samples were collected in year 2015 in the following regions from RS State: Southwest, Northeast, Northwest,
West, Southeast, Midwest and Metropolitan regions. Gender and age details are described in Table 1.

Serum samples were analyzed by neutralizing antibodies against BEV and BAV-3 through Virus Neutralization (VN) assay.

\section{Cells and Virus}

CRIB cells [8] were used throughout for virus growth, titration and VN assays. The cells were routinely maintained in Eagle's Minimum Essential Medium - MEM $\left(\mathrm{Gibco}^{\circledR}\right)^{1}$ containing penicillin $(1.6 \mathrm{mg} / \mathrm{L})$, streptomycin $(0.4 \mathrm{mg} / \mathrm{L})$ and $10 \%$ fetal calf serum $\left(\mathrm{Cultilab}^{\circledR}\right)^{2}$. The viruses used in the assays were an autochtonous isolate BEV (SV89/91) originated from an enteric and respiratory disease in bovines occurred in RS, gently donated by Professor Eduardo F. Flores (SV-UFSM) and the BAV-3 standard strain WBR-1 [6].

\section{Virus neutralization (VN) assay}

The serum samples were tested against 100 $\mathrm{TCID}_{50} / \mathrm{mL}$ of both viruses in the $\mathrm{VN}$ assay. The sera were initially inactivated for $30 \mathrm{~min}$ before use at $56^{\circ} \mathrm{C}$. A serial dilution was performed, starting at 1:5 up to $>$ $1: 640$ for BEV and starting at 1:2 to $>1: 256$ for BAV-3. All analysis were made in duplicates using 96 well microplates. The serum and virus mixture was incubated in $37^{\circ} \mathrm{C}$ for $6 \mathrm{~h}$ and then a suspension of CRIB cells was added to each well. The plates were incubated in $37^{\circ} \mathrm{C}$ and $5 \% \mathrm{CO}_{2}$ for 3 days when tested against $\mathrm{BEV}$ and 5 days when tested against BAV-3. Neutralization titers were calculated as the reciprocal of the highest serum dilution able to avoid the cytopathic effect.

\section{RESULTS}

The rates of serum samples with neutralizing antibodies to BEV and/or BAV-3 are described in Table I according to gender, age and origin.

From the 415 serum samples, 99.7\% (414) animals were serologically positive for BEV and/or BAV-3; 99.2\% (411/414) were positive only for BEV, 97.3\% (403/414); were positive only for BAV-3, and $96.6 \%$ (400/414) were positive for both viruses (see Table 1).

Regarding the gender, there were a higher number of samples from male (175) than from female cats (126) [Table I]. Separating by gender, $41.6 \%$ (120/126) of females and $100 \%$ (173/173) of males were positive for the presence of neutralizing antibodies for at least one of the viruses. 


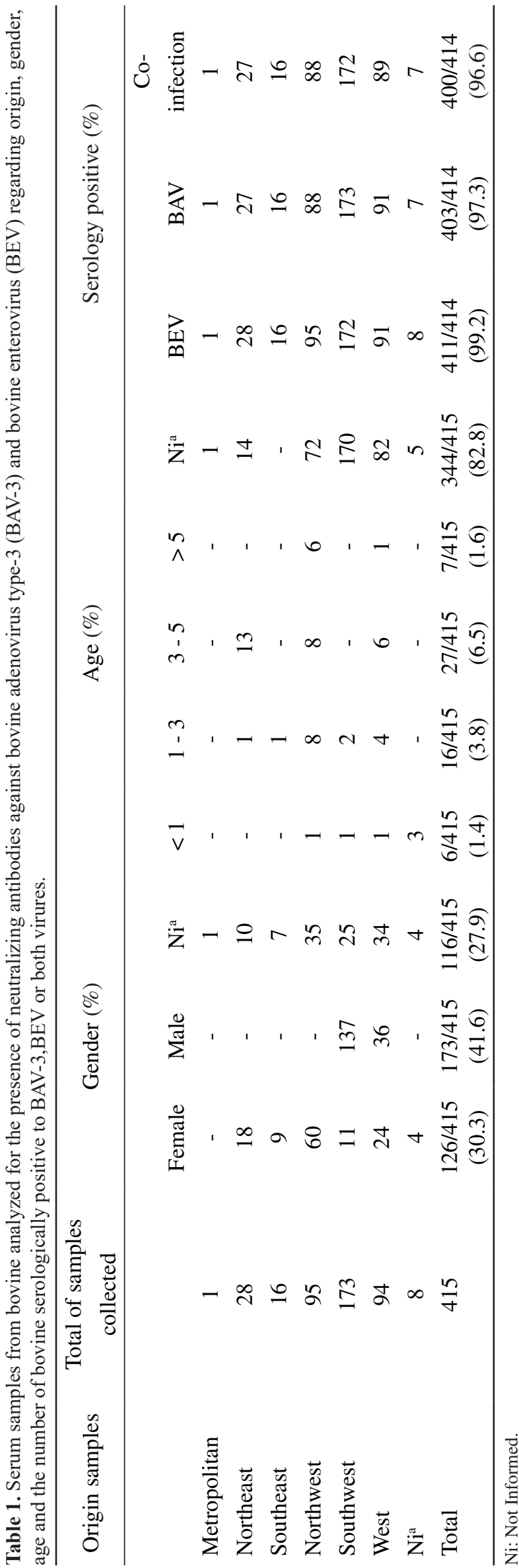

Figure 1 describes in detail the number of positive samples to each of the dilution tested, for both BEV and BAV specific antibodies, Figure 1A and 1B respectively. Titers of neutralizing antibodies against $\mathrm{BEV}$ and BAV with higher frequency were: 1:320 (2.1\% 91/411) and > 1:256 (72.2\% 291/403); and with lower frequency $1: 5(0.4 \% 2 / 411)$ and $1: 8(0.2 \% 1 / 403)$ respectively. For BAV-3, the lower dilutions $1: 2$ and 1:4 not have been detected.

\section{DISCUSSION}

The presence of detectable virus neutralizing antibodies assay demonstrated that BAV and BEV are circulating in the bovine population studied. The frequency of neutralizing antibodies against BAV than that against BEV was similar (see Table 1), although some differences were found regarding the distribution of levels of antibodies tested. Since there are no vaccines marketed in Brazil against both viruses, the presence of bovines seropositive to $\mathrm{BAV}$ and $\mathrm{BEV}$, indicates that viruses are circulation in these bovine population studied. BEV and BAV transmission may easily occur due to environmental stability of both viruses because of temperature and $\mathrm{pH}$ differences, for transmission mechanisms, oral-fecal and by BAV respiratory secretions too $[5,15,20,25]$.

High seroprevalences are expected to both BEV and BAV $[9,24,25]$, the most remarkable finding of the present study relies of the fact that Many animals with very high titers in the herds for BEV, which points to consecutive reinfections, whereas for BAV the titers are more distributed, showing that for BAV animals are infected less frequently or more recently before sampling (Figure 1). This sort of differences in antibody dynamics was found before for different viral pathogens in cattle [11,24]. This may be of interest for further decisions on the control of these infections in cattle herds.

BEV seroprevalence has been investigated in different countries. A seroprevalence study performed in Turkey, BEV was detected in six out eight mammalians species, included human beings: which $64.9 \%(986 / 1520)$ of bovine serum samples were positive to BEV, also detected by VN assay, in milk herd without clinical history that suggested infection to BEV [10]. 


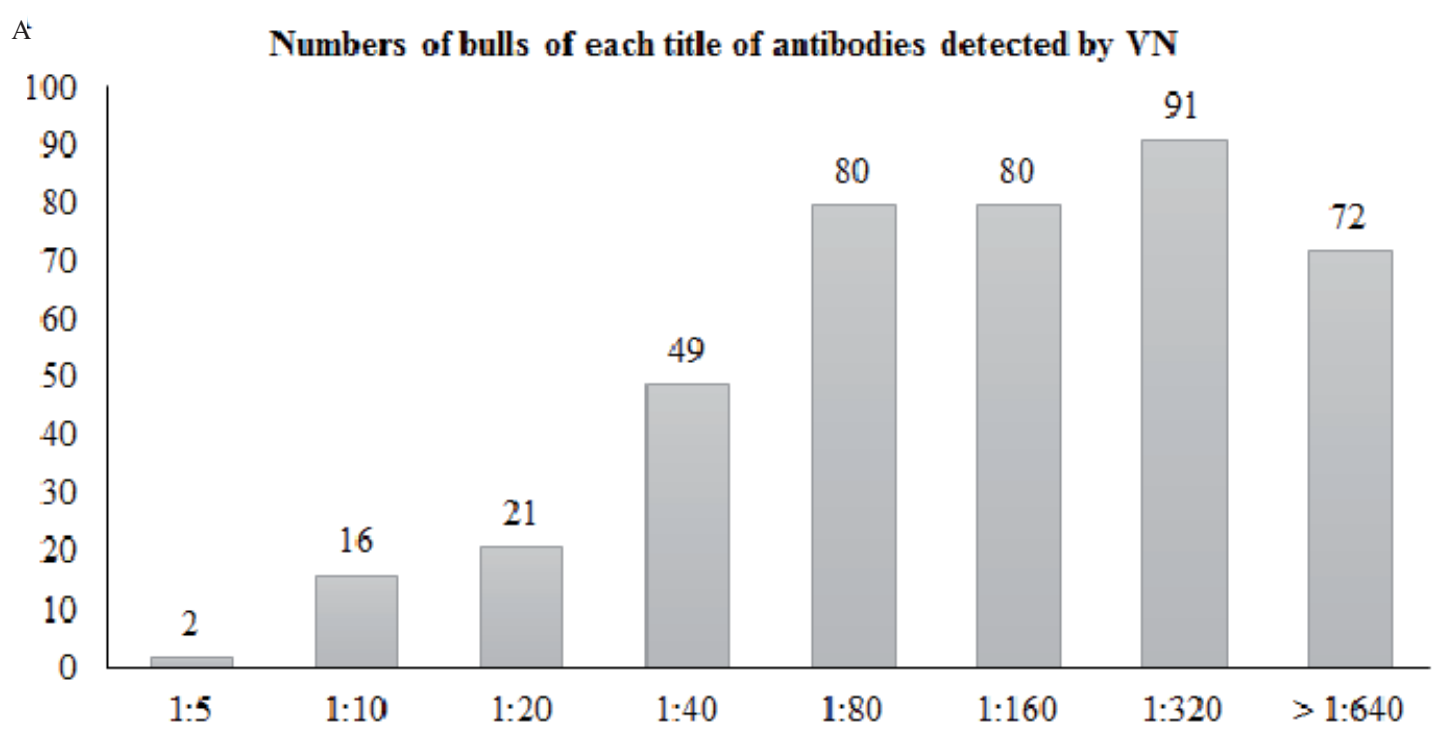

B Numbers of bulls of each title of antibodies detected by VN

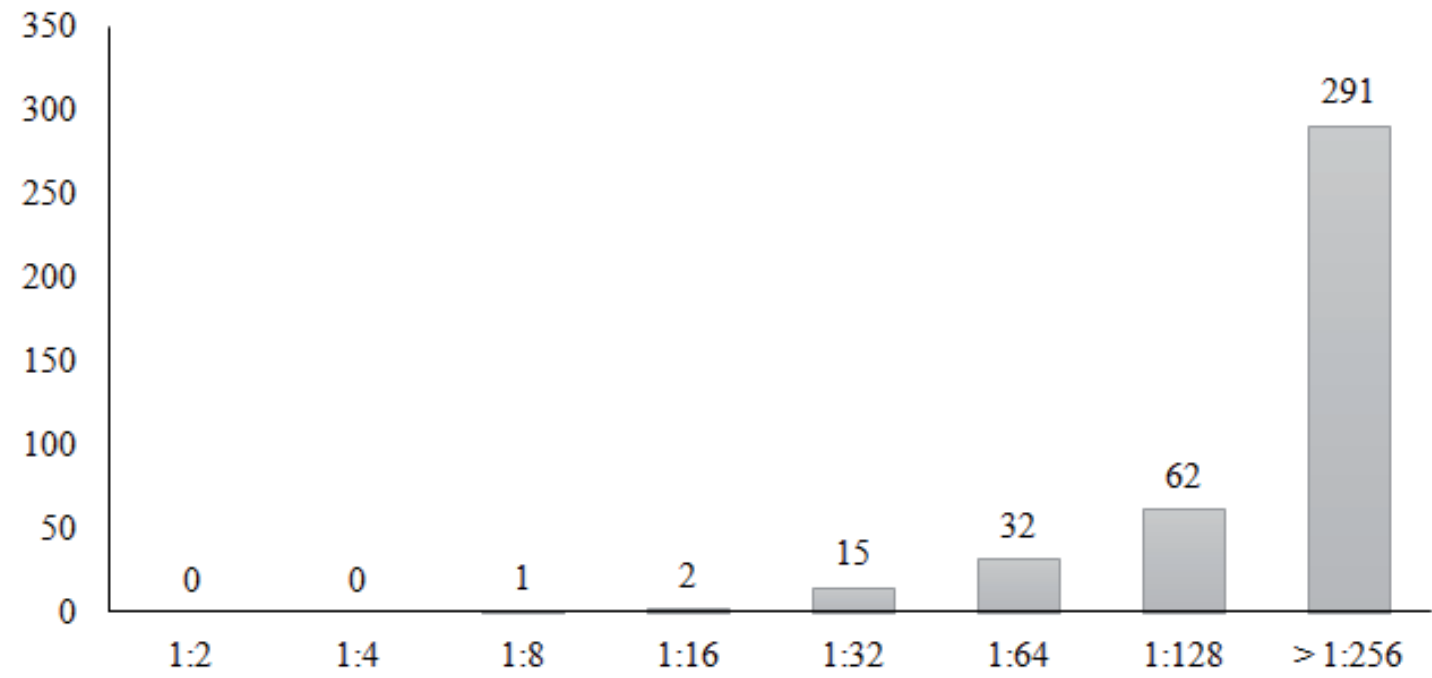

Figure 1. Titers of neutralizing antibodies detected against Bovine enterovirus (BEV) $[\mathrm{A}]$ and against Bovine adenovirus type 3 (BAV-3) [B] in serum bovine by virus neutralizing (VN).

Studies performed in China, BEV was isolated from calves with clinical signs of respiratory, gastroenteric and reprodutive disordes, which are clinical manifestations observed in BVDV infected cattle [26]. Zhang et al. [26] and Zhu et al. [27] reported isolation of $\mathrm{BEV}$ in bovines with clinical manifestations suggestive of BVDV infection; as well as bringing the importance of the diagnostic by isolation and the serological surveillance as to help in etiological affirmation [21,26,27]. The titers of specific antibodies anti-BEV in sampled population, indicates by one diversity of magnitude of highest titers than found to BAV, suggested one major number of recent infections, because the presence of animals with lower and intermediary (Figure 1A).

BAV infection is also highly prevalent in many countries. In previous studies performed in Turkey, a prevalence of $92.3 \%$ out 584 random samples in small and larger milk herds was found, even in the absence of clinical signs [25]. On the other hand, one study performed in Finland showed BAV detection in serum samples of 18 farms which were reported respiratory disorders in bovines of different 
age group, totalizing $83 \%(15 / 17)$ of seropositivity of anti-BAV antibodies [12,20].

\section{CONCLUSION}

The present study shows the distribution of infections for BEV and BAV-3 in part of bovine population regions: Southwest, Northeast, Northwest, West, Southeast, Midwest and Metropolitan of regions. As the frequency of neutralizing antibodies observed in this study was high for both viruses as well as co- -infection was prevalent, is important consider and research these viruses in animal with signs similar BVDV and BoHV or in seronegatives bovines for them.

\section{MANUFACTURERS}

${ }^{1}$ Gibco Cell Culture. São Paulo, SP, Brazil.

${ }^{2}$ Cultilab Materiais para Cultura de Celulas Ltda. Campinas, SP, Brazil.

Declaration of interest. The authors report no conflicts of interest. The authors alone are responsible for the content and writing of the paper.

\section{REFERENCES}

1 Adair B.M., McKillop E.R., Smyth J.A., Curran W.L. \& McNulty M.S. 1996. Bovine adenovirus type 10: properties of viruses isolated from cases of bovine haemorrhagic enterocolitis. The Veterinary Record. 138(11): 250-252.

2 Blas-Machado U., Saliki J.T., Boileau M.J., Goens S.D., Caseltine S.L., Duffy J.C. \& Welsh R.D. 2007. Fatal ulcerative and hemorrhagic typhlocolitis in a pregnant heifer associated with natural bovine enterovirus type-1 infection. Veterinary Pathology Online. 44(1): 110-115.

3 Boros Á., Pankovics P., Knowles N.J. \& Reuter G. 2012. Natural interspecies recombinant bovine/porcine enterovirus in sheep. Journal of General Virology. 93(9): 1941-1951.

4 Brenner J., Elad D., Bernstein M., Dagoni I., Pálfi V. \& Yadin H. 2005. The detection of an unidentified type of adenovirus in the stools of calves with weak calf syndrome by use of a commercial kit designed for the detection of human adenoviruses. Journal of Veterinary Medicine, Series B. 52(2): 98-101.

5 Comerlato J., de Oliveira L.K. \& Spilki F.R. 2011. Enterovírus como indicadores de qualidade da água. Revista Brasileira de Biociências. 9(1): 114-125.

6 Darbyshire J.H, Dawson P.S, Lamont P.H, Ostler D.C. \& Pereira HG. 1995. A new adenovirus serotype of bovine origin. Journal of Comparative Pathology. 75(3): 327-30.

7 Flores E.F. 2012. Virologia veterinária. 2.ed. Santa Maria: UFSM, 888p.

8 Flores E.F., Kreutz L.C. \& Donis R.O. 1996. Swine and ruminant pestiviruses require the same cellular factor to enter bovine cells. Journal of general virology. 77(6): 1295-1303.

9 Goens S.D., Botero S., Zemla A., Zhou C.E. \& Perdue M.L. 2004. Bovine enterovirus 2: complete genomic sequence and molecular modelling of a reference strain and a wild-type isolate from endemically infected US cattle. Journal of general virology. 85(11): 3195-3203.

10 Gür S., Yapkic O. \& Yilmaz A. 2008. Serological survey of bovine enterovirus type 1 in different mammalian species in Turkey. Zoonoses and public health. 55(2): 106-111.

11 Hage J.J., Schukken Y.H., Schols H., Maris-Veldhuis M.A., Rijsewijk F.A.M. \& Klaassen C.H.L. 2003. Transmission of bovine herpesvirus 1 within and between herds on an island with a BHV1 control programme. Epidemiology and infection. 130(3): 541-55.

12 Härtel H., Nikunen S., Neuvonen E., Tanskanen R., Kivelä S.L., Aho P. \& Saloniemi H. 2004. Viral and bacterial pathogens in bovine respiratory disease in Finland. Acta Veterinaria Scandinavica. 45(4): 1.

13 IBGE Instituto Brasileiro de Geografia e Estatistica. 2011. Produção da Pecuária Municipal. Disponível em: <http:// www.ibge.gov.br/home/estatistica/economia/ppm/2011/default.shtm>. [Acessed online in September 2015].

14 Kirkbride C.A. 1992. Viral agents and associated lesions detected in a 10-year study of bovine abortions and stillbirths. Journal of Veterinary Diagnostic Investigation. 4(4): 374-379.

15 Ley V., Higgins J. \& Fayer R. 2002. Bovine enteroviruses as indicators of fecal contamination. Applied and Environmental Microbiology. 68(7): 3455-3461.

16 McCarthy F.M., Smith G.A. \& Mattick J.S. 1999. Molecular characterisation of Australian bovine enteroviruses. Veterinary microbiology. 68(1): 71-81.

17 Narita M., Yamada M., Tsuboi T. \& Kawashima K. 2002. Immunohistopathology of calf pneumonia induced by endobronchial inoculation with bovine adenovirus 3. Veterinary Pathology Online. 39(5): 565-571. 
18 Porto R.G., Bezerra A.J.A., Porto V.H.D.F. \& Caldas N.V. 2010. Pecuária familiar: a emergência de uma categoria social no Sul do Brasil. Revista de Economia e Sociologia Rural. 48(2): 473-494.

19 Roshtkhari F., Mohammadi G. \& Mayameei A. 2012. Serological evaluation of relationship between viral pathogens (BHV-1, BVDV, BRSV, PI-3V, and Adeno3) and dairy calf pneumonia by indirect ELISA. Tropical animal health and production. 44(5): 1105-1110.

20 Shirvani E., Lotfi M., Kamalzadeh M., Noaman V., Bahriari M., Morovati H. \& Hatami A. 2012. Seroepidemiological study of bovine respiratory viruses (BRSV, BoHV-1, PI-3V, BVDV, and BAV-3) in dairy cattle in central region of Iran (Esfahan province). Tropical animal health and production. 44(1): 191-195.

21 Sobhy N.M., Mor S.K., Mohammed M.E.M., Bastawecy I.M., Fakhry H.M., Youssef C.R.B. \& Goyal S.M. 2015. Isolation and molecular characterization of bovine enteroviruses in Egypt. The Veterinary Journal. 206(3): 317-321.

22 Spilki F.R., de Oliveira L.K., Dalla Vecchia A., Comerlato J., Frezza R. \& dos Santos J.V.S. 2009. Deteç̧ão e desinfecção de vírus em dejetos de ruminantes. Revista Conhecimento Online. 1: 1-15. [Fonte: <http://aplicweb.feevale. br/site/files/documentos/pdf/32677.pdf >].

23 Stott E.J., Thomas L.H., Collins A.P., Crouch S., Jebbett J., Smith G.S. \& Caswell R. 1980. A survey of virus infections of the respiratory tract of cattle and their association with disease. Journal of Hygiene. 85(2): 257-270.

24 Uttenthal Å., Larsen L.E., Philipsen J.S., Tjørnehøj K., Viuff B., Nielsen K.H. \& Nielsen T.K. 2000. Antibody dynamics in BRSV-infected Danish dairy herds as determined by isotype-specific immunoglobulins. Veterinary microbiology. 76(4): 329-341.

25 Yeşilbağ K. \& Güngör B. 2008. Seroprevalence of bovine respiratory viruses in North-Western Turkey. Tropical animal health and production. 40(1): 55-60.

26 Zhang H., Liu H., Bao J., Guo Y., Peng T., Zhou P. \& Gao M. 2014. Characterization of an enterovirus species E isolated from naturally infected bovine in China. Virus research. 191: 101-107.

27 Zhu L., Xing Z., Gai X., Li S., San Z. \& Wang X. 2014. Identification of a novel enterovirus E isolates HY12 from cattle with severe respiratory and enteric diseases. PloS one. 9(5): e97730. 